\title{
A Pathological Inhibitor of Fibrin Cross-Linking
}

\author{
L. Lorand, A. Jacobsen, and Joyce Bruner-Lorand
}

From the Biochemistry Division, Department of Chemistry, Northwestern

University, Evanston, Illinois

A в S T R A C T Lewis et al. recently reported on a patient who died of hemorrhages attributable to an acquired inhibitor of fibrin-stabilizing factor. They indicated that the inhibitor was associated with the immune globulins. Using the postmortem serum in the isolated fibrin cross-linking system, we have now further localized the site of inhibition in the scheme of blood coagulation. The interference occurs at the transpeptidation step catalyzed by the thrombin-activated fibrin-stabilizing factor. The patient's serum also uniquely delayed the clotting time of Homarus plasma, a test for specific inhibitors of transpeptidation. Since the inhibitor was effective in two such widely different systems, it probably is not an antibody, but falls into the category of cross-linking inhibitors which we have previously described $(4,5,10,12-17)$. While the exact nature of the inhibitor remains unknown, we raise the question whether some unusual metabolic transformation of isonicotinic acid hydrazide (with which the patient was treated and which itself we found to be a potent inhibitor fibrin crosslinking), in combination with a macromolecule, might not have given rise to an inhibitory compound.

\section{INTRODUCTION}

Clotting of fibrinogen in vertebrates is controlled by two enzyme systems. Limited proteolysis by thrombin first removes negatively charged fibrinopeptide fragments (1-3) which results in the low-

Address requests for reprints to Dr. Lorand, Biochemistry Division, Department of Chemistry, Northwestern University, Evanston, Ill. 60201

Recciz'd for publication 18 August 1967 and in revised form 14 Scptcmber 1967. ering of protein solubility (at physiological $\mathrm{pH}$ and ionic strength) so that a gel forms. More important, however, release of the peptides is accompanied by the uncovering of critical functional groups $(4,5)$ which can subsequently cross-link in a transpeptidating reaction to form $\gamma$-glutamyl- $\epsilon-$ lysine bonds (5-7), catalyzed by the thrombin-activated fibrin-stabilizing factor $\left[\mathrm{FSF}^{*} ;(8,9)\right]$. This scheme of events represents a synchronized mechanism whereby thrombin seems to control the rates of appearance of both the substrate (fibrin) and the enzyme (FSF*) for cross-linking. Though it is already recognized that there must be other identifiable intermediates $(4,10,11)$, the overall steps in the biosynthetic sequence of normal clot formation could simply be represented as in Fig. 1.

By contrast, the fibrinogen of Homarus is apparently ready to participate in transpeptidation without the prior necessity of hydrolytic unmasking of its cross-linking sites. Homarus clotting thus represents a shunt of the vertebrate scheme of clot formation, and Homarus fibrinogen may be considered to be the soluble (at the $\mathrm{pH}$ and ionic strength of blood) equivalent of vertebrate fibrin (12).

There are a large number of compounds which, by simulating the donor amino or carbonyl acceptor transpeptidating functions of fibrin, selectively interfere only with the cross-linking reaction in vertebrates, but have no effect whatsoever on gel formation per se. These same compounds, however, greatly delay the clotting time of Homarus plasma $(4,5,10,12-17)$. It follows that Homarus clotting could serve as a valuable diagnostic tool for detecting such inhibitors of fibrin cross-linking if these 


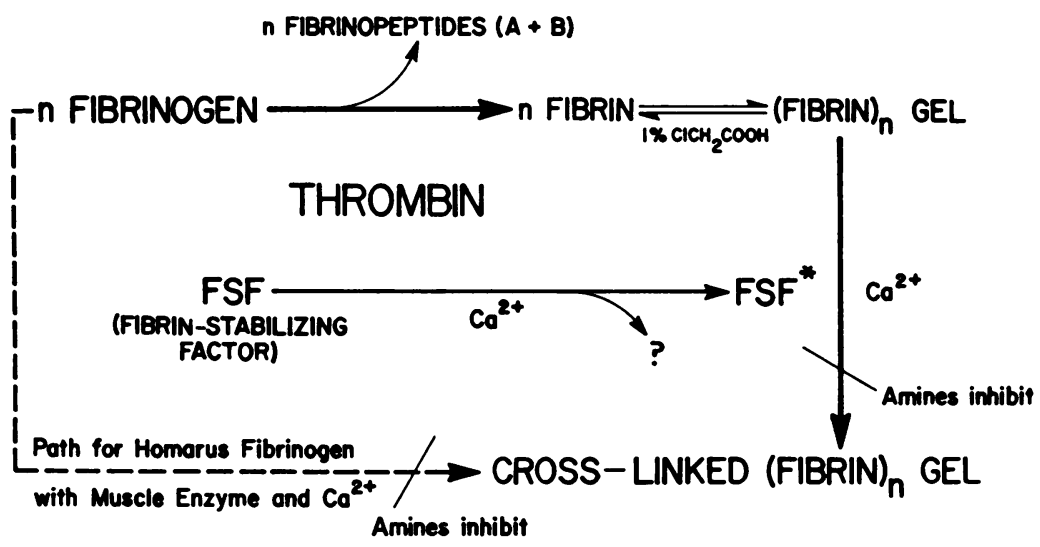

FIGURE 1 After the formation of thrombin from prothrombin, the reaction sequence in vertebrates, leading to a cross-linked clot, is outlined by the solid arrows. The shunt representing clot formation in Homarus is shown by the broken arrow. A large number of compounds (e.g. amines of various types) specifically inhibit cross-linking (i.e. transpeptidation) of vertebrate fibrin without affecting gel formation, and also delay the clotting of Homarus fibrinogen. This fact could be interpreted to mean that transpeptidation might have been the original mechanism in blood clotting.

were present in, shall we say, human serum $(12$, $18,19)$.

Many of the inhibitors described are quite similar to physiologically or pharmacologically occurring substances. Hence, there was a distinct possibility, as was pointed out earlier $(18,19)$, that an excessive concentration of these inhibitors accumulating in blood might give rise to pathological manifestations in regard to fibrin stabilization. The serum of a patient with such a condition would, by definition, on one hand prevent the formation of $1 \%$ monochloroacetic acid-insoluble (20) structures in the isolated fibrin cross-linking system of vertebrates and, on the other, inhibit the clotting of Homarus plasma.. The present paper shows the application of these concepts in the analysis of the coagulation defect of a patient who died of a bleeding disorder (21).

\section{METHODS}

Inhibition of fibrin cross-linking. This phenomenon was studied in the bovine system previously described $(13,14)$, with the following outlines.

(a) Activation of $0.4 \mathrm{ml}$ (1.2 $\mathrm{mg}$ of protein) of plasma fibrin-stabilizing factor (22) with $0.1 \mathrm{ml}$ of thrombin [2 NIH units; purified by the method of Rasmussen (23) ; Thrombin Topical, Parke, Davis \& Co., Detroit, Mich.] was carried out by addition of $0.5 \mathrm{ml}$ of $1 \mathrm{~mm}$ calcium chloride and $0.5 \mathrm{ml}$ of $0.1 \mathrm{M}$ cysteine, for a duration of $10 \mathrm{~min}$. (b) Quenching of thrombin after the activation step was accomplished by $0.2 \mathrm{ml}$ of $0.25 \mathrm{M} N^{\alpha_{-}} p$ -
toluenesulfonyl-L-arginine methylester (TAMe). (c) The patient's (R.H.) serum or normal serum (S.T.), each in various dilutions with a buffer, was added in a volume of $0.5 \mathrm{ml}$. (d) Cross-linking reaction was initiated by the vigorous admixing of $0.3 \mathrm{ml}$ of fibrin $(4.5 \mathrm{mg}$ of protein in $1 \mathrm{M}$ sodium bromide, adjusted to $\mathrm{pH} 5.4$ with acetic acid) (24), and it was allowed to proceed for $30 \mathrm{~min}$. (e) Then $2.5 \mathrm{ml}$ of $2 \%$ monochloroacetic acid was added to terminate the cross-linking reaction and to disperse those portions of the clots which did not cross-link. $(f)$ The acid-insoluble clot residues remaining after about $18 \mathrm{hr}$ in the $1 \%$ monochloroacetic acid were photographed and then centrifuged, washed, and digested to measure their protein contents.

Fibrin-stabilizing factor, thrombin, cysteine, TAMc, and serum dilutions were made up in $0.05 \mathrm{M}$ tris (hydroxymethyl) aminomethane- $0.1 \mathrm{M}$ sodium chloride buffer adjusted to $\mathrm{pH} 7.4$ with hydrochloric acid.

The experiments were performed at room temperature $\left(\sim 24^{\circ} \mathrm{C}\right)$.

Tests for inhibiting Homarus blood clotting. The tests were carried out in a manner previously described (12). In $10 \times 75 \mathrm{~mm}$ culture tubes, $0.2 \mathrm{ml}$ of the above Tris buffer was mixed with $0.1 \mathrm{ml}$ of $0.2 \mathrm{M}$ calcium chloride and $0.1 \mathrm{ml}$ of Homarus tissue coagulin ( $1 \mathrm{mg}$ of protein) obtained from the tail muscle. (Dilutions of the enzyme in Fig. 4 were made up in the Tris buffer). Then, $0.1 \mathrm{ml}$ (Fig. 4) and $0.2 \mathrm{ml}$ (Fig. 5) of human serum or glycine methylester (each in various dilutions with the Tris buffer) were added. The clotting reaction was initiated by the introduction of $0.2 \mathrm{ml}$ of citrated Homarus plasma, and gel formation was noted by tilting of the tubes. All tests were performed at room temperature $\left(\sim 24^{\circ} \mathrm{C}\right)$. 

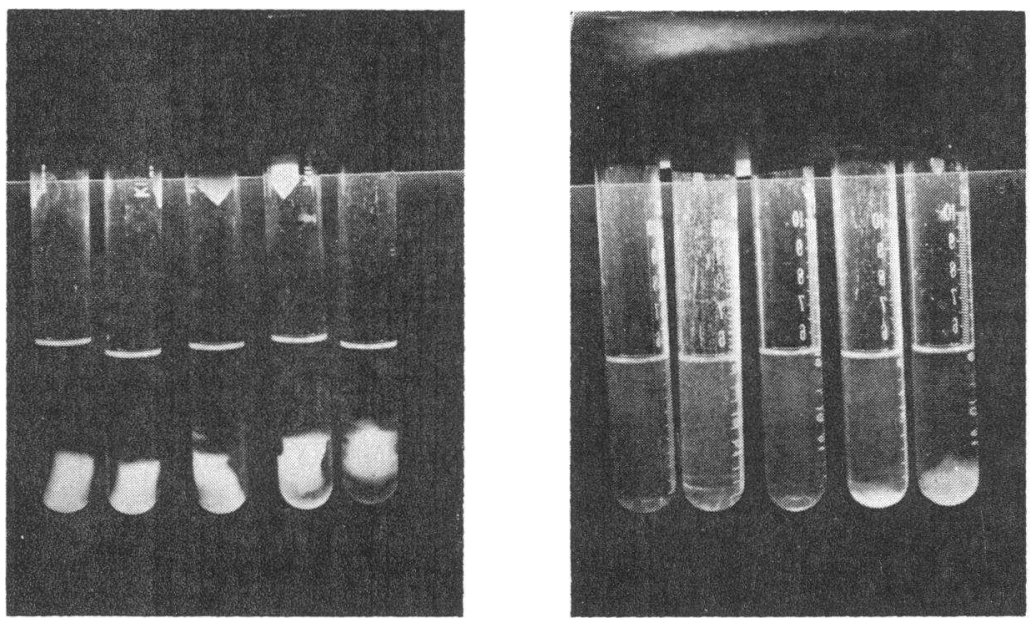

FigURE 2 Monochloroacetic acid-insoluble clot residues, after exposing fibrin to cross-linking conditions in the presence of normal serum (on left) or the patient's (R.H.) serum (on right). For experimental details, see text. Serum added in each set, from left to right: $0.5,0.4,0.3,0.2$, and $0.1 \mathrm{ml}$.

\section{RESULTS AND DISCUSSION}

Assays pertaining to inhibition of fibrin crosslinking are summarized in Figs. 2 and 3. The photographs (Fig. 2), taken $18 \mathrm{hr}$ after the addition of monochloroacetic acid, clearly show that small concentrations of the patient's (R.H.) serum partially inhibited acid-insoluble fibrin formation, and larger concentrations caused complete inhibition. Normal serum (S.T.), in contrast, had no effect on the

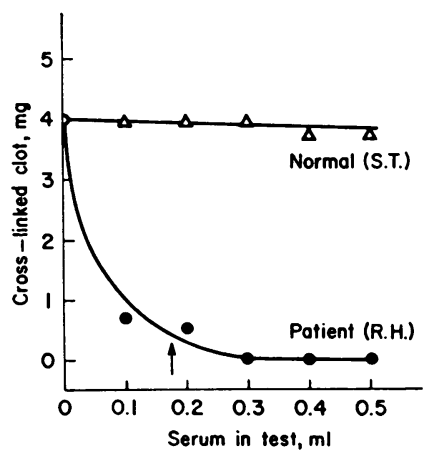

FIgURE 3 Inhibition of cross-linking by the patient's (R.H.) serum, seen in Fig. 2, is quantitated by measuring the protein contents of monochloroacetic acidinsoluble clot residues. As already noticed in Fig. 2, normal serum (S.T.) caused no inhibition at all. The vertical arrow indicates on the curve the approximate extent of cross-linking which would have occurred if, in lieu of the patient's serum, $16 \times 10^{-4} \mathrm{M}$ glycine methylester or $16 \times 10^{-5} \mathrm{M}$ isonicotinic acid hydrazide had been present as inhibitor. cross-linking reaction. These visual findings are expressed quantitatively in Fig. 3, where the ordinate shows the protein contents of the cross-linked cores of clots, insoluble in $1 \%$ monochloroacetic acid. Also, the degree of inhibition caused by the patient's serum is compared with the effect of glycine methylester, a cross-linking inhibitor standard.

It should be recalled that our test system utilizes purified fibrin which is cross-linked uncler the influence of preactivated FSF* (see Fig. 1). Therefore, it can now be stated with assurance that the inhibition caused by the patient's serum is actually directed against the functioning of the thrombin-activated fibrin-stabilizing factor in crosslinking the clot. The more general survey tests (21), in which the transformation of fibrinogen, activation of FSF, and the cross-linking reaction proper are not separated from each other, would not, of course, permit such a specific conclusion.

Since cross-linking was prevented by the patient's serum in spite of the presence of $20 \mathrm{~mm}$ cysteine, this inhibition does not resemble the kind of interference seen by polymyxin B sulfate (25).

The finding that the patient's serum greatly delayed the clotting time of Homarus plasma (Figs. 4 and 5 ) further supports the idea that the inhibitor is directed against the transpeptidation step itself. The exceptional occurrence of such an inhibitor is underlined by the finding that, of about 60 samples of human sera (from normal indi- 
viduals and from patients with various disorders), not a single one caused any delay whatsoever in the clotting time of Homarus plasma.

In accord with the earlier report (21), the inhibitory activity could not be removed from the patient's serum $(1 \mathrm{ml})$ by dialysis overnight at $4^{\circ} \mathrm{C}$ against 1 liter solution of $0.05 \mathrm{~m}$ Tris- $0.1 \mathrm{M}$ sodium chloride, $\mathrm{pH}$ 7.4. Furthermore, full inhibition was displayed by the serum liquor after refluxing at $100^{\circ} \mathrm{C}$ for $10 \mathrm{~min}$. Nondialyzability would suggest that the inhibitor was present as (or in combination with) a macromolecular component of the patient's serum. However, the unusual heat stability would indicate that the inhibitor probably does not depend on the native properties of serum proteins. Hence, we would find it difficult to assume that the pathological inhibitor was really an "anti factor XIII" (21) in the sense of being a suddenly acquired antibody either to FSF [ which is the species denoted as coagulation factor XIII; (26)] or to FSF* itself. Also, the fact that the inhibitor interfered with two so widely different enzyme proteins as bovine plasma FSF* and Homarus tissue coagulin would in all likelihood rule out the possibility that the patho-

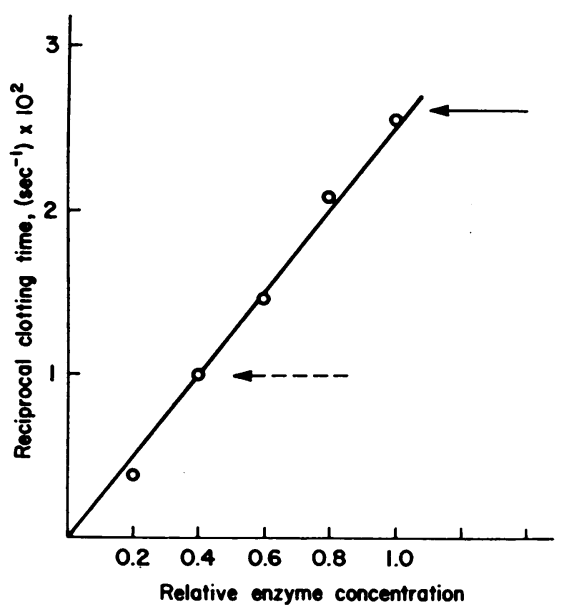

FigURE 4 The straight line $(O)$ shows the relationship between enzyme concentration $(1.0 \equiv 1 \mathrm{mg}$ of tissue coagulin protein) and speed of clotting of Homarus plasma in the absence of inhibitor. When $0.1 \mathrm{ml}$ of the patient's (R.H.) serum was present, with a relative enzyme concentration of 1.0, a speed of clotting (indicated by the broken arrow) corresponding only to 0.4 in relative enzyme concentration was obtained. Hence, the patient's serum inhibited $60 \%$ of the activity of the Homarus enzyme in this test. Normal serum under identical conditions had no effect at all (solid arrow).

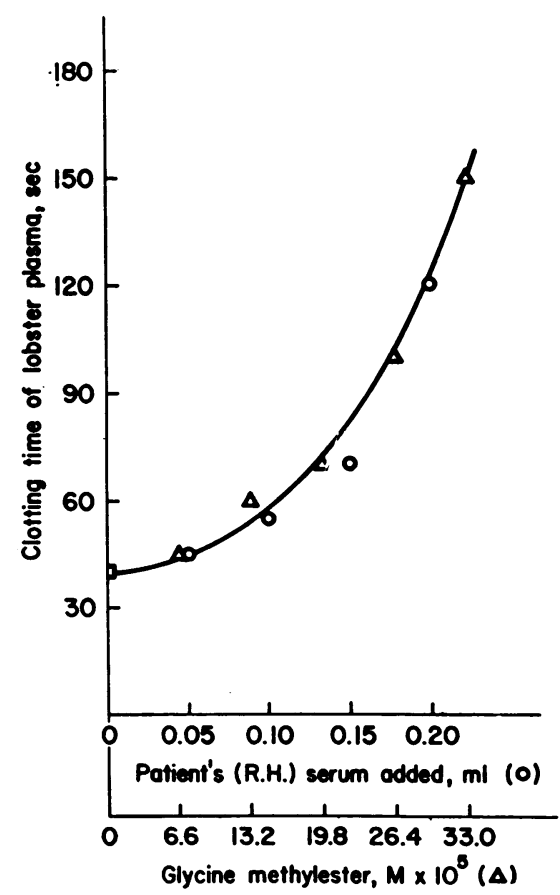

Figure 5 Delay in the clotting time of Homarus plasma caused by the patient's (R.H.) serum is compared with the effect of a simple inhibitor, glycine methylester. The character of both inhibitions seems to be identical.

logical manifestation was due to an antibody against the thrombin-activated fibrin-stabilizing factor.

Although we are thus of the opinion that it is unlikely that the pathological manifestation was due to an antibody, exact cause of the defect can only be a matter of pure conjecture at this time. The alternatives are clearly too many to enumerate. However, a curious coincidence between our own work with in vitro inhibitors of fibrin cross-linking of various types and the patient's history raises a possibility which merits consideration, namely that isonicotinic acid hydrazide might have had a role in this particular case. The latter compound

$$
\left(\mathrm{R} \cdot \mathrm{CO} \cdot \mathrm{NH} \cdot \mathrm{NH}_{2} ; \mathrm{N}\right.
$$

happens to be the most potent inhibitor of fibrin cross-linking (27) found so far, and the patient (R.H.) "had been treated with isoniazid (100 mg three times per day) for a number of years" (21). Since many other individuals under such treatment did not seem to have acquired a similar in- 
hibitor, if isonicotinic acid hydrazide was at all involved in this instance, one would obviously assume that the drug in patient R.H. was metabolized in an unusual manner. Since, in general, the metabolic transformations of isonicotinic acid hydrazide are only partially understood, and since a wide range of individual variations are noted (e.g. ref. 28), this is not an inconceivable assumption. The fact that the inhibitor could not be removed by dialysis would seem to exclude the possibility that inhibition was due to the presence of excessive concentrations of free isoniazide in the patient's serum. This compound, however, could have become tightly bound to, or, perhaps even more important, actually might have chemically modified, a macromolecular component of the serum. Considering just the latter case involving a blood protein $\left(\mathrm{H}_{2} \mathrm{~N} \cdot \mathrm{P} \cdot \mathrm{CO} \cdot \mathrm{NH}_{2}\right.$, with two common reactive groups shown), isonicotinic acid hydrazide could have participated in a variety of reactions, possibly enzyme catalyzed. Only a few of the exchange types will be illustrated:

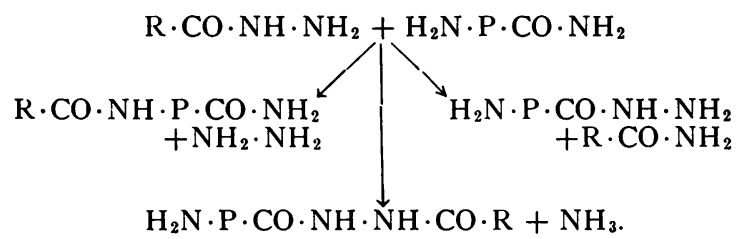

From what we know about the chemistry of transpeptidation in the final stage of blood coagulation for cross-linking fibrin, any of these three derivatives of a protein (or of a large peptide) could be a potent inhibitor. It should be noticed that, after acid hydrolysis, two of the protein derivatives shown would yield free isonicotinic acid, whereas the third would give rise to free hydrazine. Thus, some of these ideas could conceivably be tested even with the exceedingly small quantities of this patient's serum still available. Because of this circumstance, however, careful planning will be required to approach the chemical identification of the inhibitor in a meaningful way.

\section{ACKNOWLEDGMENTS}

Thanks are due to Dr. Jessica $\mathrm{H}$. Lewis of the University of Pittsburgh School of Medicine for sending us a sample of the serum from patient R.H. (21).

This work was aided by a U. S. Public Health Service Research Career Award and by grants from the National Heart Institute, National Institutes of Health (HE02212), and the American Heart Association.

\section{REFERENCES}

1. Lorand, L. 1951. Fibrino-peptide. New aspects of the fibrinogen-fibrin transformation. Nature. 167: 992.

2. Lorand, L. 1952. Fibrino-peptide. Biochem. J. 52: 200.

3. Bettelheim, F. R., and K. Bailey. 1952. Biochim. Biophys. Acta. 9: 578.

4. Lorand, L., and H. H. Ong. 1966. Labeling of amineacceptor cross-linking sites of fibrin by transpeptidation. Biochemistry. 5: 1747.

5. Lorand, L., H. H. Ong, B. Lipinski, N. G. Rule, J. Downey, and A. Jacobsen. 1966. Lysine as amine donor in fibrin crosslinking. Biochem. Biophys. Res. Commun. 25: 629.

6. Lorand, L., and H. H. Ong. 1966. Studies on fibrin cross-linking. Nature of the acceptor groups in transpeptidation. Biochem. Biophys. Res. Commun. 23: 188.

7. Bruner-Lorand, J., T. Urayama, and L. Lorand. 1966. Transglutaminase as a blood clotting enzyme. Biochem. Biophys. Res. Commun. 23: 828.

8. Lorand, L., and K. Konishi. 1964. Activation of the fibrin stabilizing factor of plasma by thrombin. Arch. Biochem. Biophys. 105: 58.

9. Konishi, K., and L. Lorand. 1966. Separation of activated fibrin-stabilizing factor from thrombin. Biochim. Biophys. Acta. 121: 177.

10. Lorand, L. 1965. Physiological roles of fibrinogen and fibrin. Federation Proc. $24: 784$.

11. Kézdy, F. J., L. Lorand, and K. D. Miller. 1965. Titration of active centers in thrombin solutions. Standardization of the enzyme. Biochemistry. 4: 2302.

12. Lorand, L., R. F. Doolittle, K. Konishi, and S. K. Riggs. 1963. A new class of blood coagulation inhibitors. Arch. Biochem. Biophys. 102: 171.

13. Lorand, L., K. Konishi, and A. Jacobsen. 1962. Transpeptidation mechanism in blood clotting. Nature. 194: 1148.

14. Lorand, L., and A. Jacobsen. 1964. Specific inhibitors and the chemistry of fibrin polymerization. Biochemistry. 3: 1939.

15. Bruner-Lorand, J., T. R. E. Pilkington, and L. Lorand. 1966. Inhibitors of fibrin crosslinking: Relevance for thrombolysis. Nature. 210: 1273.

16. Lorand, L., A. Jacösen, and R. Schuel. 1964. Inhibitors of fibrin polymerization. Biol. Bull. 127: 379. (Abstr.)

17. Lorand, L., T. R. E. Pilkington, and J. BrunerLorand. 1965. A search for new inhibitors of fibrin crosslinking. Biol. Bull. 129: 413. (Abstr.)

18. Lorand, L. 1963. The clotting of fibrinogen and a new class of blood coagulation inhibitors. Thromb. Diath. Haemorrhag. 13 (Suppl.) : 45.

19. Lorand, L. 1963. The terminal steps of blood coagulation. Proc. 9th Congs. European Soc. Haematol., Lisbon. S. Karger, Basel, New York. 1237.

20. Lorand, L. 1950. Fibrin clots. Nature. 166: 694.

21. Lewis, J. H., I. L. F. Szeto, L. D. Ellis, and W. L. Bayer. 1967. An acquired inhibitor to coagulation factor XIII. Johns Hopkins Med. J. 120: 401. 
22. Loewy, A. G., C. Veneziale, and M. Forman. 1957. Purification of the factor involved in the formation of urea-insoluble fibrin. Preliminary note. Biochim. Biophys. Acta. 26: 670.

23. Rasmussen, P. S. 1955. Purification of thrombin by chromatography. Preliminary note. Biochim. Biophys. Acta. 16: 157.

24. Donnelly, T. H., M. Laskowski, Jr., N. Notley, and H. A. Scheraga. 1955. Equilibria in the fibrinogenfibrin conversion. II. Reversibility of the polymerization steps. Arch. Biochem. Biophys. 56: 369.
25. Marshall, F. N., and E. N. Massad. 1967. Interference with fibrin stabilization by polymyxin B sulfate. Proc. Soc. Exptl. Biol. Med. 125: 420.

26. Report of the Committee on Nomenclature of Blood Clotting Factors. 1963. Thromb. Diath. Haemorrhag. Suppl. 13.

27. Lorand, L., and A. Jacobsen. 1967. Isonicotinic acid hydrazide as an inhibitor of transpeptidation. Relevance for blood coagulation. Nature. 216: 508.

28. Goodman, L. S., and A. Gilman. The pharmacological basis of therapeutics. The Macmillan Co., New York. 3rd edition. 1322. 